\title{
Small-scale patchiness of the chlorophyll- fluorescence in the sea: aspects of instrumentation, data processing, and interpretation
}

\author{
H. Astheimer ${ }^{1}$ and H. Haardt ${ }^{2}$ \\ ${ }^{1}$ Alfred-Wegener-Institut für Polarforschung, Columbus-Center, D-2850 Bremerhaven, Federal Republic of Germany \\ ${ }^{2}$ Institut für angewandte Physik, Universität, Olshausenstr., D-2300 Kiel, Federal Republic of Germany
}

\begin{abstract}
Burst' series consisting of 5 chlorophyll-fluorescence profiles at 3 min intervals were taken every hour at 3 drift stations over periods of about $15 \mathrm{~h}$ each in the transition zone between North and Baltic Seas using a fluorescence sonde, pre-calibrated into in vivo Dunaliella chlorophyll units. Differences in the field between fluorometric readings and water samples analysed photometrically were not significant. Chlorophyll layers in the Kattegat were about $1 \mathrm{~m}$ thick, floating on isopycnal surfaces. Microscale horizontal variability (= standard deviation of 1 burst of profiles) was generally high, reaching a maximum in the pycnocline at high chlorophyll concentrations. Mesoscale variability (= standard deviation of all profiles) observed in chlorophyll, temperature and salinity, may be due to horizontal displacement, advection, and internal waves. It appears impossible for the data presented here to separate the spatial and temporal components of the chlorophyll distribution pattern.
\end{abstract}

\section{INTRODUCTION}

The dynamics of phytoplankton distribution in the euphotic zone is controlled by: (1) biological processes of growth depending on light and nutrients; (2) hydrographical processes determining cell buoyancy (i.e. light level), dispersion and nutrient uptake; (3) ecological processes within the foodweb such as zooplankton grazing. The subject has been investigated by many workers (e.g. Gessner, 1948; Kierstead and Slobodkin, 1953; Steele, 1974; Platt et al., 1977; Okubo, 1980).

Whereas the standing stock of phytoplankton under situations with low vertical variability can very well be assessed photometrically as the chlorophyll content of water-bottle samples (Kreps and Verbinskaya, 1930; Jeffrey and Humphrey, 1975), this method is usually not suitable for determining the vertical structure and the degree of chlorophyll patchiness. Defining patchiness as the variability (i.e. standard deviation) of chlorophyll in the space-time regime, a high sample density is needed that can only be obtained from continuous sampling techniques such as in vivo fluorometry (Herman, 1975; Früngel and Koch, 1976;
Denman, 1977; Herman and Denman, 1977). An increasing number of workers make use of the advantages of fluorometric sondes mounted on conductivitytemperature-depth (CTD) systems (Derenbach et al., 1979; Horwood, 1976, 1978; Kahru et al., 1981). In only a few cases, though, have significance and reliability of the results been demonstrated by a detailed description of the data processing techniques used.

Many biological oceanographers hesitate to trust in vivo chlorophyll fluorometry because the emittance of fluorescent light depends on many intracellular and extracellular factors (Kiefer, 1973; Loftus and Seliger, 1975; Samuelsson and Oquist, 1977; Slovacek and Hannan, 1977; Stienen, 1981; Rai and Marker, 1982).

It is our first aim to show that a fluorometric sonde can indeed be used successfully to monitor the distribution of chlorophyll under in situ conditions. Determination of spatio-temporal scales of phytoplankton patchiness, the second aim, is difficult because of the many interfering processes. This paper presents the static (averaged) aspect of 3 hydrographical stations. Dynamical features of chlorophyll distribution are discussed elsewhere (Astheimer, 1983). 


\section{STUDY AREA}

All data were collected during a $10 \mathrm{~d}$ cruise of RV 'Poseidon' in March 1979. The sampling program comprised 3 drift stations (No. 28, 78, 107; Fig. 1) and a

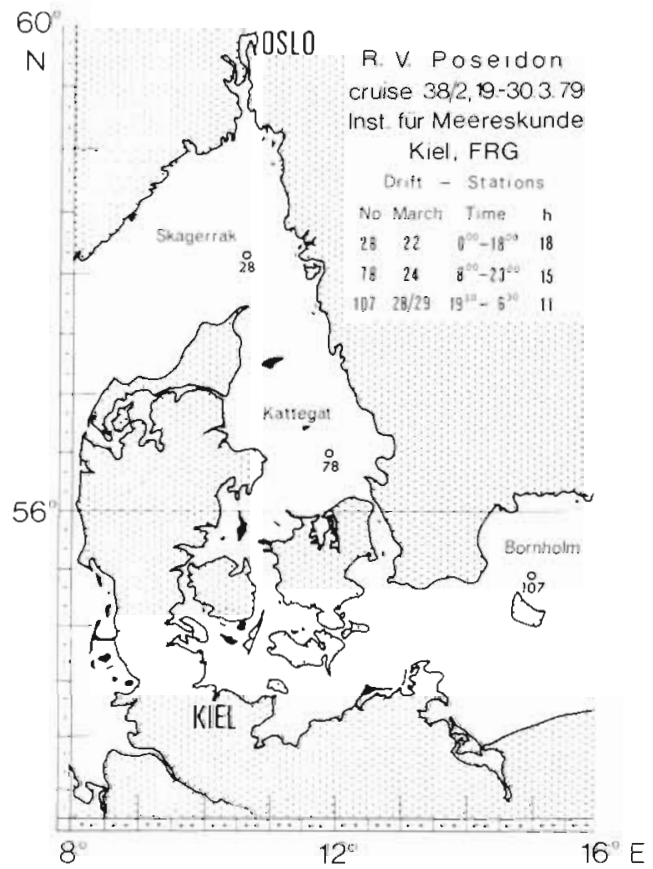

Fig 1 Location of the 3 drift stations. Not indicated are the positions of 25 water-sample stations scattered evenly over the area

total of 25 water-sample stations. The latter were scattered along the crusse track: from Skagerrak in the north, through Kattegat down to Kiel Bight in the south, and east up to Bornholm Basin.

The generalised hydrography of this transition zone between the North Sea and Baltic Sea is depicted in Fig. 2. Surplus of fresh water in the Baltic leads to an

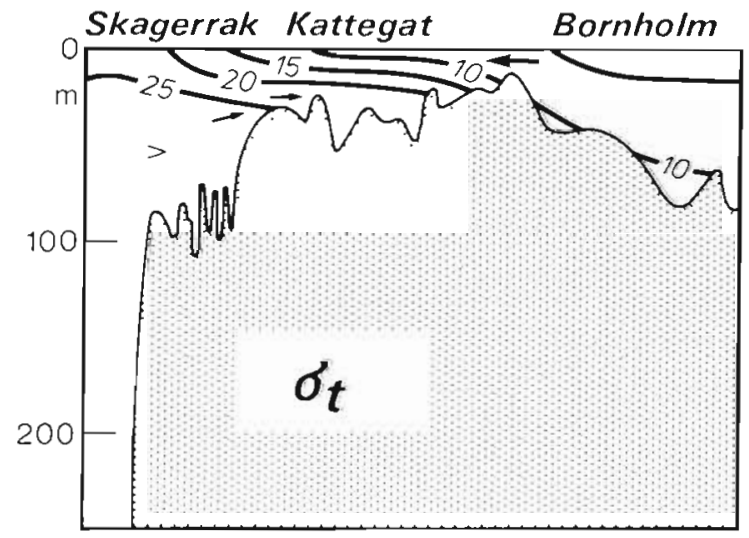

Fig 2 Density distribution in the transition zone between North Sea and Baltıc Sea Arrows: mean currents (Modified after Siedler and Hatje, 1974)

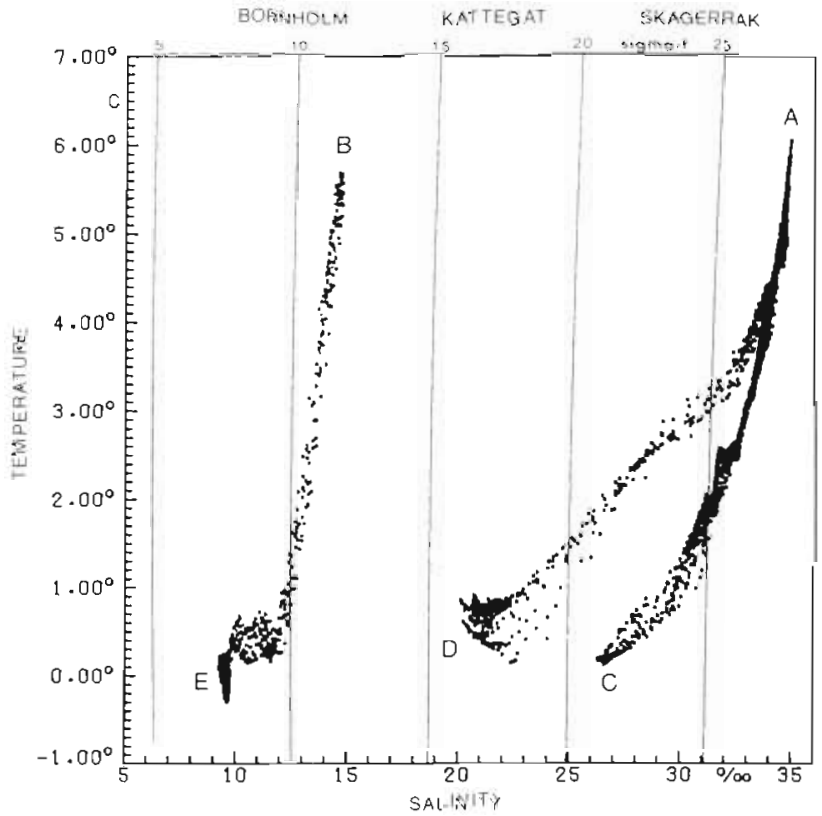

Fig 3. T-S diagram combining mean hourly temperature and salınity values from drift stations. (A) Skagerrak, Kattegat, bottom water; (B) Bornholm, bottom water; (C) Skagerrak, surface water; (D) Kattegat, surface water; (E) Bornholm, surface water

outflow of light surface water into the North Sea. Below the very strong halocline, heavy bottom water flows slowly into the Baltic. This average circulation pattern is quite variable, depending on the actual meteorological situation.

The T-S diagram (Fig. 3) combines all mean hourly temperature and salinity values from the drift stations. On each statıon, the $T$-S values are concentrated in the upper water layer at low temperatures, and in the lower layers at higher temperatures.

\section{INSTRUMENTS, CALIBRATIONS AND METHODS}

\section{Fluorescence sonde \\ Instrument design}

For measurements we used a submersible fluorescence sonde (Fig. 4 A; Electro Optics Suarez, HenstedtUlzburg, FRG) previously described by Früngel et al. (1971), Frungel and Koch (1976, 1980), Hundahl and Holck (1980), Aiken (1981), Fasham et al. (1981) and others. Our instrument deviates from the instruments introduced by the above-mentioned authors in its mechanical dimensions, filters and optics, as well as in electronic circuitry. It is insensitive to daylight and Mie scattering. Our fluorometer consists of 2 parallelmounted pressure cases (Fig. $4 \mathrm{~A}_{1} \mathrm{~B}$ ). The transmitter 


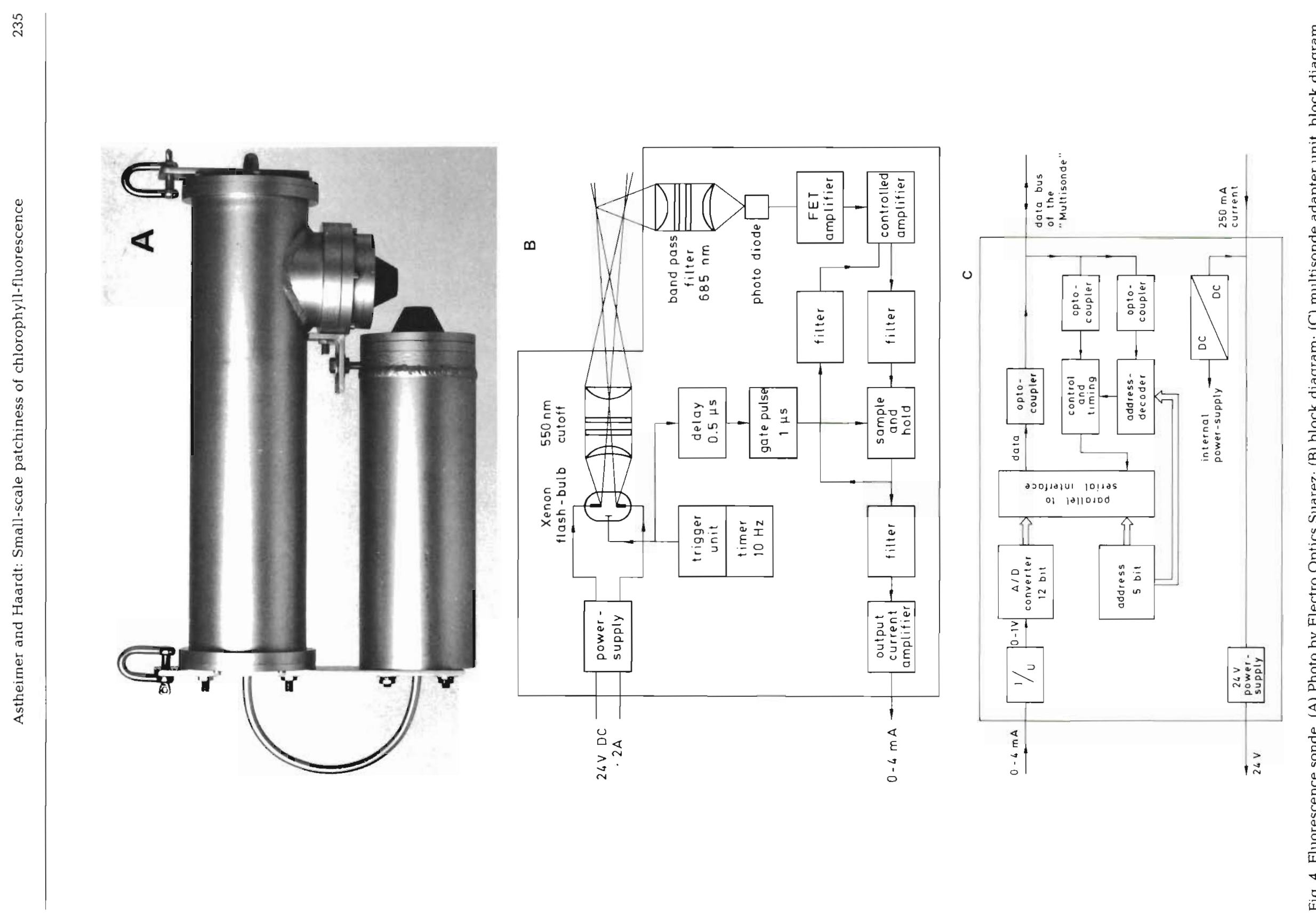


contains the Xenon spark discharge lamp, excitation filters, focussing optics, power electronics, repetition rate generator, and triggering circuitry. The receiver contains receiving optics and filters, a photodiode as the sensing element, and signal-processing circuitry. Fluorescence is excited at wavelengths between 390 and $550 \mathrm{~nm}$ by Xenon light pulses of $2 \mu$ s duration at a repetition rate of $10 \mathrm{~Hz}$. Radiation is focussed to a beam spot of 6 by $2 \mathrm{~mm}^{2}$ with an irradiance of about $200 \mathrm{~kW} \mathrm{~m}^{-2}$, ensuring light saturation even for high sample concentrations.

Sampling volume (cross-volume of optical cones of receiver and transmitter) is about $0.1 \mathrm{~cm}^{3}$. The fluorescent light emitted by chlorophyll $a$ at $685 \mathrm{~nm}$ passes an interference filter (wavelength $685 \mathrm{~nm}$, halfwidth $20 \mathrm{~nm}$ ) and is focussed on a photodiode, whose current enters an AC-coupled amplifier with controlled gain. After noise-reducing filtering, the signal passes a sample-and-hold amplifier, gated by a trigger pulse derived from the ignition pulse of the lamp. About

\section{Calibration of the Fluorescence Sonde}

A

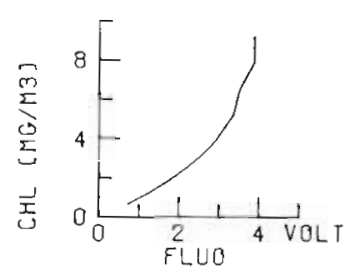

B

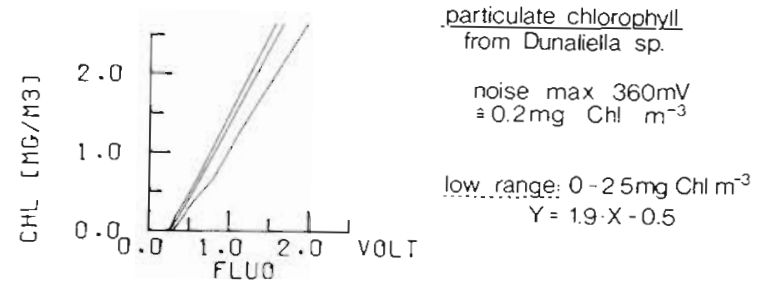

(voltage-chlorophyll-a)

dissolved chlorophyll

electronic noise max. $25 \mathrm{mV}$ $\equiv<0.01 \mathrm{mg} \mathrm{Chl} \mathrm{m} \mathrm{m}^{-3}$ (after Stienen, 1981)
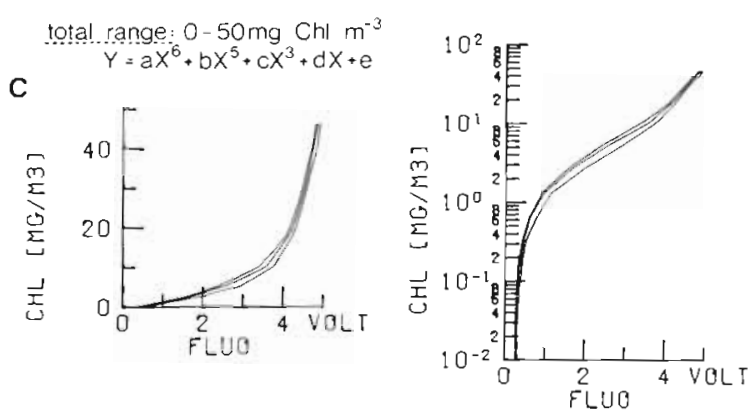

D
$0.5 \mu$ s after each ignition pulse, the detector becomes sensitive for about $1 \mu \mathrm{s}$. The output signal of the sample-and-hold amplifier can be averaged with time constants selectable between 0.7 (which we used) and $20 \mathrm{~s}$. It is first converted into a current between 0 and $4 \mathrm{~mA}$, then into a 12 bit integer (Fig. $4 \mathrm{C}$ ), and transmitted to the Multisonde. Output voltage of the sample-and-hold amplifier controls the gain of the preamplifier. This results in the nonlinear characteristics of the instrument (Fig. 5). The time constants are asymmetric and concentration-dependent, in the linear range ( 0 to $1 \mathrm{~mA}$ ) 0.5 and $0.7 \mathrm{~s}$, in the log range $(>1 \mathrm{~mA}) 0.2$ and $0.7 \mathrm{~s}$ for ascending and descending values, respectively. Arithmetic averaging therefore overestimates strong events maximally by $35 \%$ if the duration of the event is $0.7 \mathrm{~s}$ (corresponding to $35 \mathrm{~cm}$ vertically at $50 \mathrm{~cm} \mathrm{~s}^{-1}$ ), and by $10 \%$ for events lasting 0.06 or $5 \mathrm{~s}$, respectively.

\section{Laboratory calibration}

Our fluorometer had previously been calibrated by Stienen (1981) who used crystalline chlorophyll from spinach chloroplasts dissolved in acetone (Fig. $5 \mathrm{~A}$ ). The electronic noise of the instrument, as detected in this way, reaches a maximum of $25 \mathrm{mV}$ which corresponds to less than $0.01 \mathrm{mg} \mathrm{Chl} \mathrm{m}^{-3}$ (determined photometrically after Jeffrey and Humphrey, 1975).

In our own calibration (Fig. 5 B-D), we used living Dunaliella cells giving rise to a much higher noise

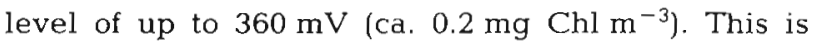
probably due to the small sampling volume detecting patchiness on a very small scale, and should be negligible for most fjeld surveys.

The response of the fluorometer is linear in the low range (Fig. $5 \mathrm{~B}$ ) and logarithmic in the upper range (Fig. $5 \mathrm{C}, \mathrm{D}$ ). This was accounted for by applying appropriate calibration formulae. (Any phytoplankton species other than Dunaliella can be used for in vivo calibrations without changing the general shape of the curves presented here.)

\section{Field calibration}

During our cruise the fluorometer was mounted on the 'Kiel Multisonde' (Kroebel et al., 1976), together with sensors for pressure, temperature, temperature gradient, conductivity, acceleration, oxygen, attenuation at $670 \mathrm{~nm}$, and light scattering (Fig. 6). Sampling rate was 4 times $\mathrm{s}^{-1}$; data were averaged and recorded on tape ( 1 value $s^{-1}$ ). Water samples were pumped on board through a hose, the lower end of which was tightened to the frame of the Multisonde, with its
Fig. 5. Calibration of Fluorescence Sonde (voltage $\rightarrow$ chlorophyll a), each plot consisting of 3 curves: minimum, average, and maximum fluorometer output. (A) Crystalline chlorophyll dissolved in acetone (Stienen, 1981); (B-D) 'particulate' chlorophyll (Iiving Dunaliella sp. cells); (B) low range with linear response; (C-D) upper range with logarithmic response $\mathrm{a}=0.015308, \mathrm{~b}=-0.078661, \mathrm{c}=0.489415, \mathrm{~d}$ $=0.283544, \mathrm{e}=0.649825$; (D) logarithmic representation (chlorophyll saturation above $4 \mathrm{~V}$ ) 


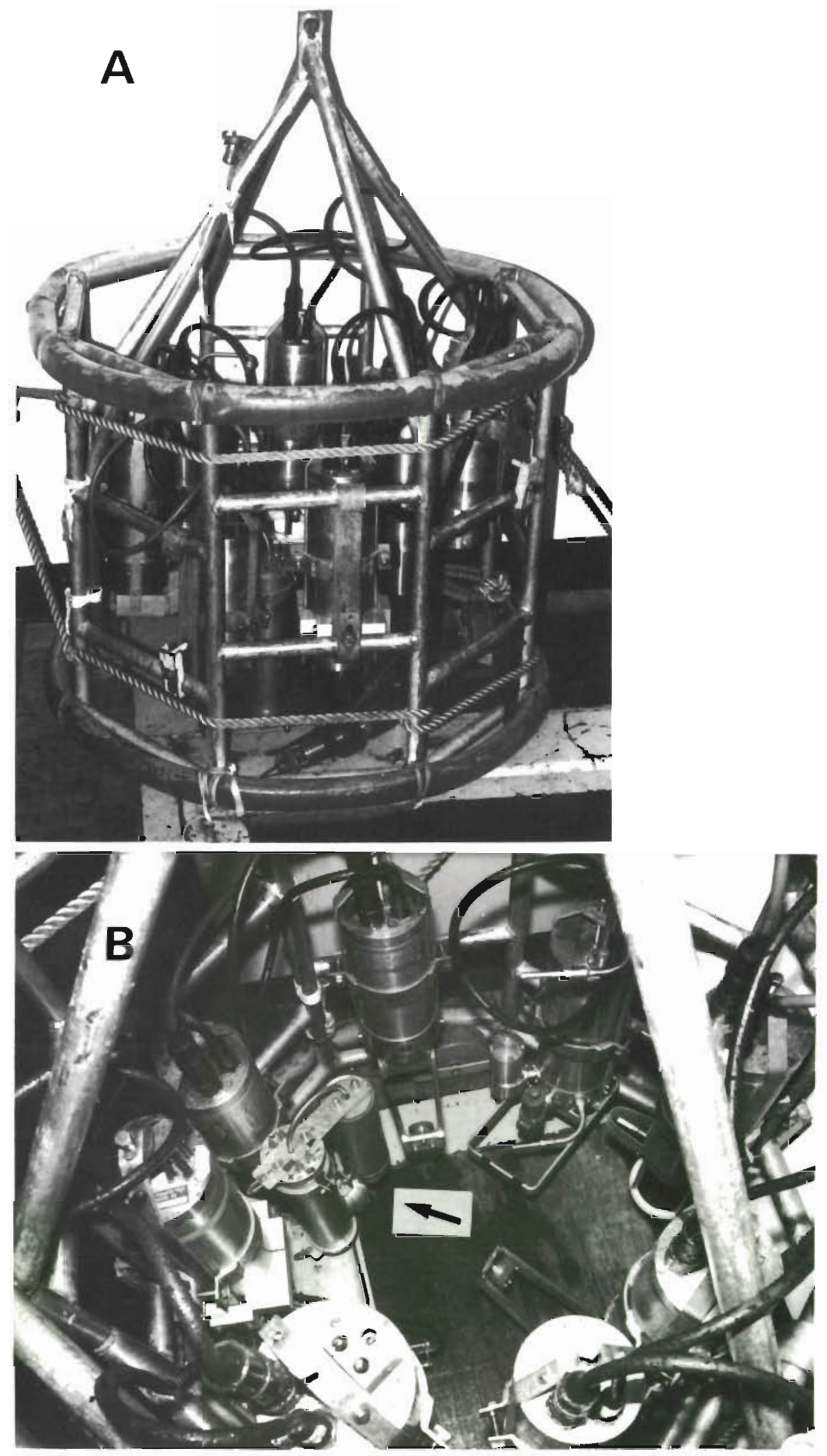

Fig. 6. Kiel Multisonde, additionally equipped with fluorometer. (A) Total view; (B) internal arrangement of sensors (arrow pointing at fluorometer) 
suction inlet only a few cm away from the sampling volume of the fluorescence sonde. Sampling depths were selected individually for each station after examination of a test profile of the distribution of salinity and fluorescence. Then, starting with the lowest depth, the Multisonde remained positioned at each depth until enough water had been collected.

Fig. 7 exemplifies the fluorescence signal obtained in this way. Horizontal 'bars' reveal a high degree of

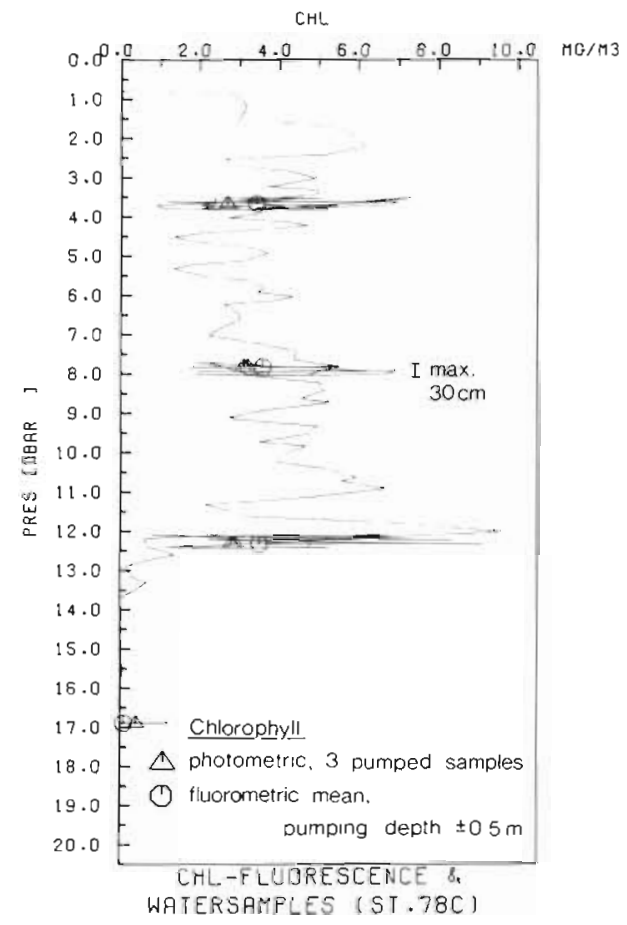

Fig. 7. In situ calibration of fluorescence sonde. Ascending chlorophyll profile (pre-calibrated fluorescence) and water samples (photometric chlorophyll a)

horizontal patchiness in the water drifting by during the pumping periods. Vertical width of the bars (max. $30 \mathrm{~cm}$ ) is a result of the Multisonde's and ship's upand-down movement due to surface waves. (The remainder of the curve is of little interest, since the fine

Table 1. In situ chlorophyll fluorescence and water samples (cf. Fig. 7)

\begin{tabular}{|c|c|c|c|c|}
\hline \multicolumn{5}{|c|}{ Chlorophyll (mg $\mathrm{m}^{-3}$ ) } \\
\hline & photometric & fluor & metric & \\
\hline Depth (m) & mean $(N=3)$ & mean & std. dev. & $\mathrm{N}$ \\
\hline 3.7 & 2.70 & 3.43 & 1.47 & 69 \\
\hline 7.8 & 3.13 & 3.59 & 1.41 & 45 \\
\hline 12.3 & 2.83 & 3.51 & 2.37 & 61 \\
\hline 16.9 & 0.40 & 0.09 & 0.28 & 30 \\
\hline 23.1 & 0.33 & - & - & - \\
\hline
\end{tabular}
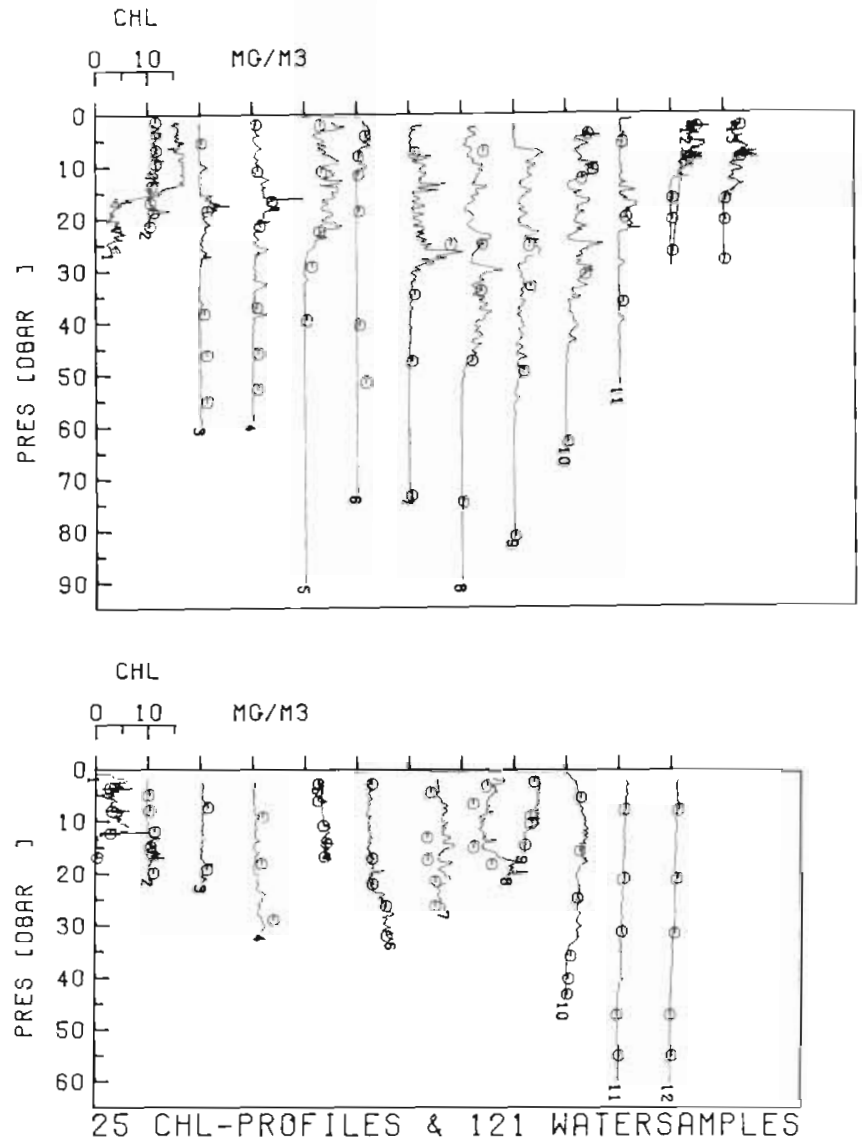

Fig. 8. Ensemble of 25 profiles (fluorometric) and 121 water samples 10 , photometric) for in situ calibration

structure is detectable in descending profiles only, due to the downward orientation of the sensors.) Means and standard deviations of all fluorescence data points within \pm 0.5 dbar around each sampling depth are

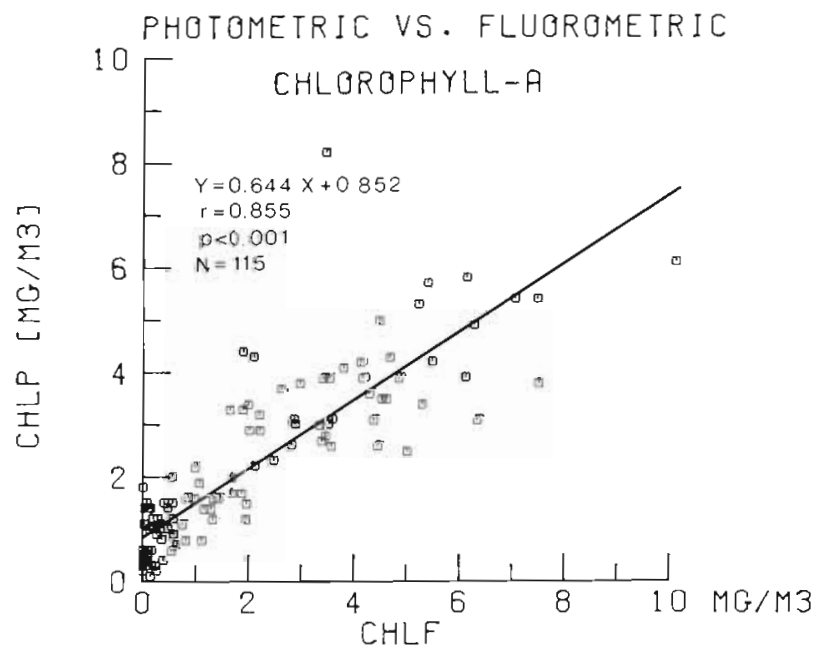

Fig. 9. Scatter diagram and regression line of fluorometric and photometric data pairs (from Fig. 8, excluding 6 mavericks from first profile: $₫$ ) 
given in Table 1, combined with averages of 3 replicate water samples analysed photometrically.

A complete set of fluorometric and photometric data was compiled for all 25 stations (Fig. 8) and evaluated statistically. Linear regression between data pairs (Fig. 9) reveals a high degree of correlation. The scatter (standard error of estimate $=1.1 \mathrm{mg} \mathrm{Chl} \mathrm{m}^{-3}$ ) may be attributed to the local fluorescence yield of the algae, and primarily to the fact that the volumes of water sampled were quite different for the 2 instruments (fluorescence sonde: photometer $\approx 1: 30$ ). A paired t-test (Nie et al., 1975) indicated that the mean difference between fluorometric and photometric chlorophyll determinations was not significantly different from zero. The mean difference \pm standard deviation was $-0.134 \pm 1.156 \mathrm{mg} \mathrm{m}^{-3}(\mathrm{~N}=115 ; \mathrm{p}=$ 0.215 ). For this reason, re-calibration was considered unnecessary, especially when looking primarily at relative changes in the vertical phytoplankton distribution. Thus all chlorophyll concentrations in this paper refer to laboratory Dunaliella equivalents.

\section{Drift stations and data processing}

To reduce the influence of advective processes to a minimum, time series of chlorophyll profiles (presented in the following sections) were made in drifting bodies of water. At each drift station (cf. Fig. 1), buoys were used to label a certain water mass, and profiling was done with the ship following these buoys (Astheimer, 1982). Every hour, a series of 5 Multisonde profiles ('burst') was done at 3 min intervals (Fig. 10). From these profiles ( $\Delta p=0.1$ to 0.2 dbar) a single grand mean profile was computed on one side, and a series of hourly mean profiles on the other $(\Delta p=0.5$ dbar). The latter were further filtered (moving average over 11 values $\triangleq 5.5 \mathrm{dbar}$ ) in order to isolate the gross features (low pass) from the fine structure (high pass) of the vertical phytoplankton distribution.

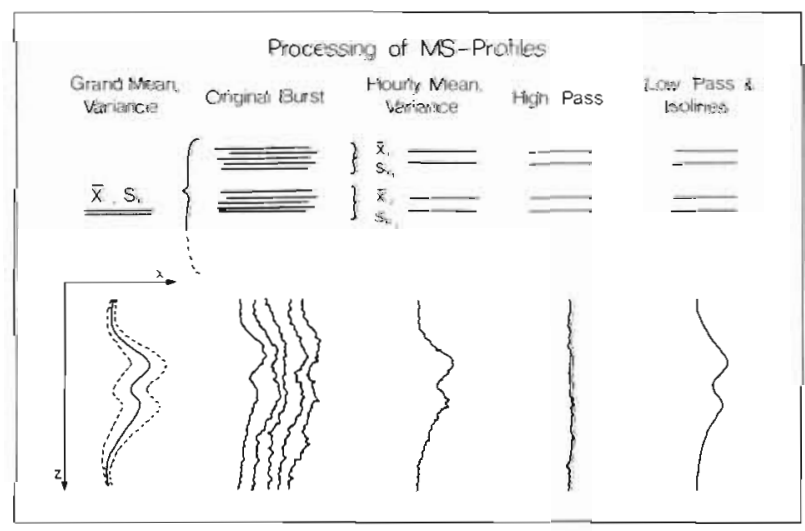

Fig. 10. Processing of Multisonde profiles (drift stations)

\section{RESULTS}

\section{Microscale chlorophyll patchiness}

Original chlorophyll profiles from a single burst (Fig. 11) reflect a high degree of small-scale horizontal variability. In view of the noise level during laboratory

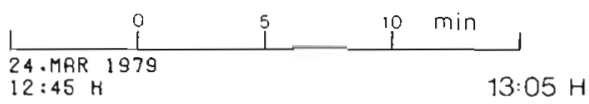

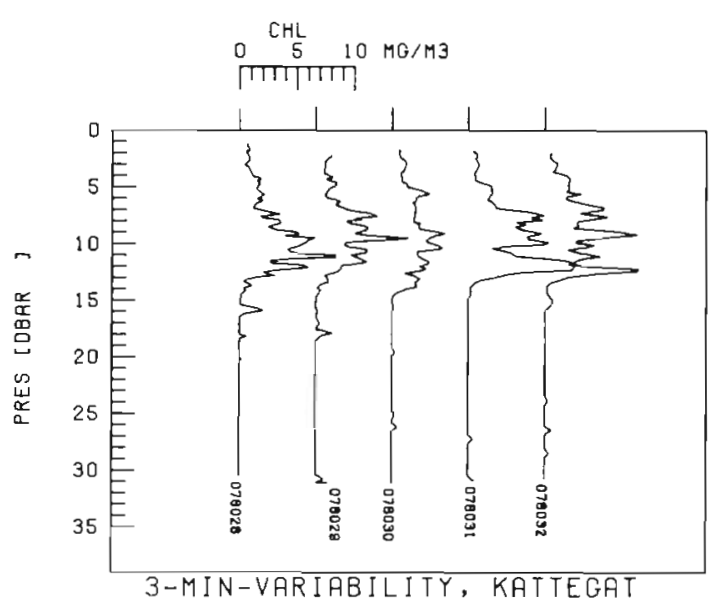

Fig. 11. Small-scale horizontal variability of chlorophyll layers in a single 'burst' of 5 profiles ( $\Delta p \approx 0.1 \mathrm{dbar}$, profiling speed $\left.\approx 0.4 \mathrm{~m} \mathrm{~s}^{-1}\right)$

calibrations (p. 236), the thin peaks ( $\Delta$ p $<0.4$ dbar) might be unreal due to the small sampling volume of the fluorometer. The thicker chlorophyll layers $(\Delta p$ $\geqslant 1.0$ dbar) must be considered real features and unaffected by the response time of the instrument. They carry more than 20 fluorescence samples, at least 10 with increasing and 10 with decreasing chlorophyll concentrations. None of the structures seen in Fig. 11 can be traced from the first to the last profile with confidence. There are changes in their thickness (Table 2) and depth position, and in their maximum chlorophyll concentration.

The whole series of original profiles from the Kattegat drift station is depicted in Fig. $12 \mathrm{~A}$. Due to unavoidable overlap of individual profiles no details are discernible. The chlorophyll distribution in the upper layer of water ( 0 to 15 dbar) is quite patchy and variable. Below the thermocline, in the lower layer (cf. Fig. $15 \mathrm{~A}$ ), there is almost no phytoplankton.

Much of the small-scale horizontal variability is eliminated by computing mean hourly profiles (Fig. 12 B). Although even here individual peaks do not show up in consecutive profiles, it is a general feature that chlorophyll concentrations increase stepwise from the surface down to the thermocline. 
Table 2. Thickness of chlorophyll layers in the original burst profiles of Fig. 11 (depth difference between neighboring chlorophyll minima)

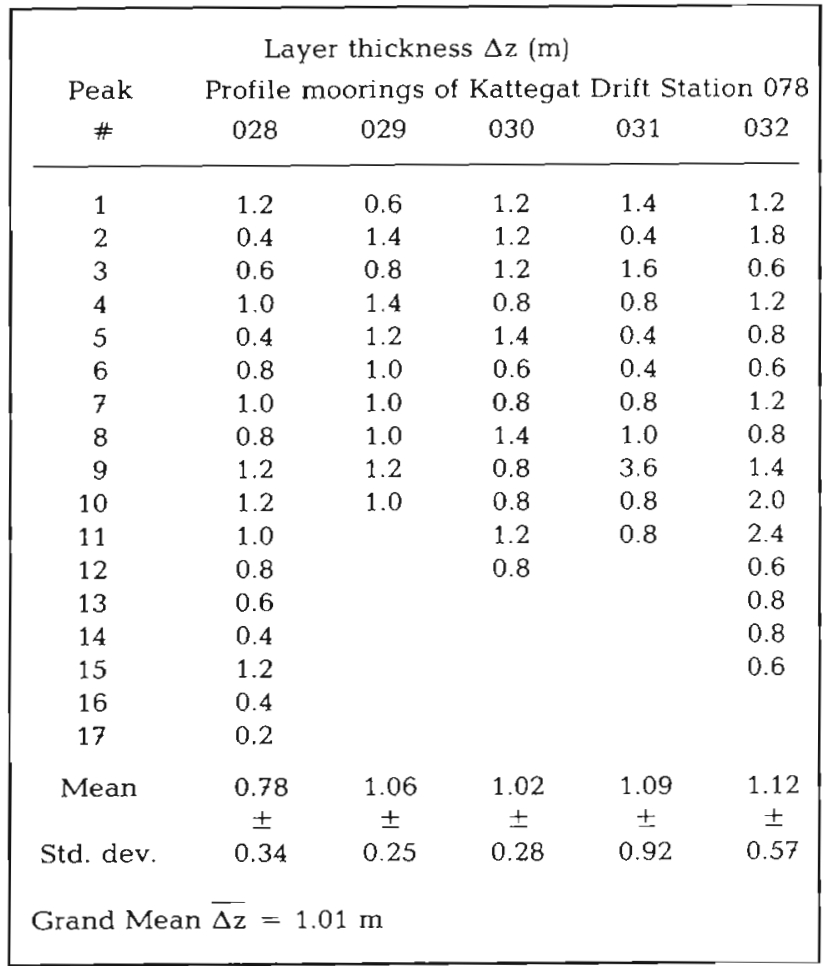

The standard deviation profiles (Fig. 12 C) can be taken as a measure of the small-scale horizontal varia-

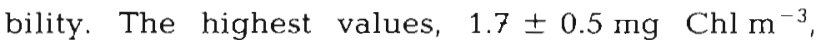
appear in the upper part of the thermocline at $11 \pm 3$ dbar. To be precise, these profiles also contain a certain amount of vertical variability (of up to $0.7 \pm 0.4 \mathrm{mg} \mathrm{Chl} \mathrm{m}^{-3}$; Astheimer, 1982) since the pressure interval was enlarged vertically from the original 0.1 or $0.2 \mathrm{dbar}$ to $0.5 \mathrm{dbar}$.

The fine structure of the vertical chlorophyll distribution is shown in the high pass profiles of Fig. $12 \mathrm{D}$. (During computation, 'negative chlorophyll concentrations' may result since the smoothed hourly profiles were subtracted from the mean hourly profiles of Fig. 12 B.) They represent the structures smaller than $2.75 \mathrm{~m}$ vertically that are local modifications of the general gross distribution pattern, which can be further used to determine phytoplankton patch sizes (Astheimer, 1983). The differences encountered between consecutive profiles even at the depth of the drift buoy ( 1 to 6 dbar) must be attributed to horizontal patchiness on length scales greater than $100 \mathrm{~m}$.

The vertical distribution of all quantities in a density gradient is strongly influenced by internal waves (Fig. 11 and 13). They give rise to vertical oscillations introducing some error when computing mean profiles along isobars. Replacing the pressure coordinate with

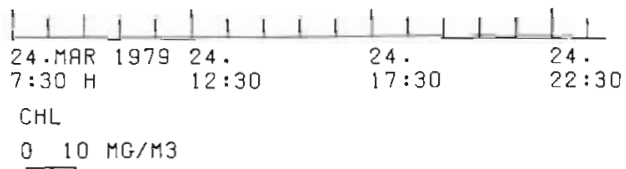

$0 \quad 10 M G / M 3$

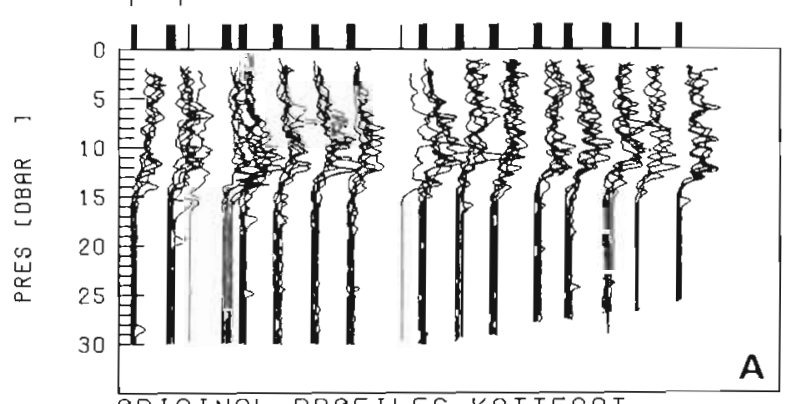

ORIGINAL PROFILES KATTEGAT

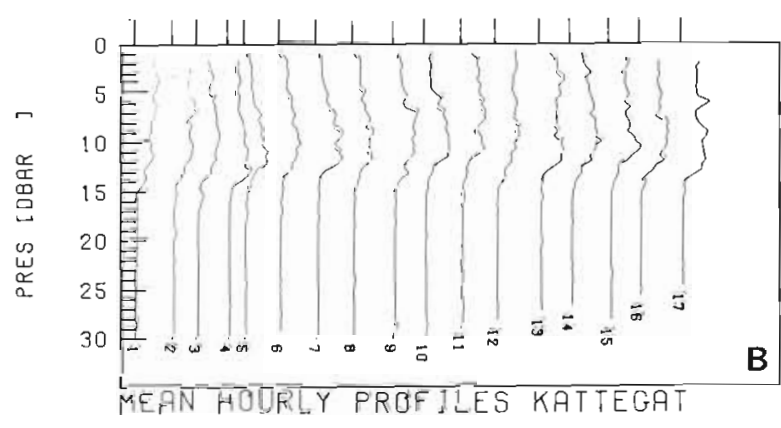

$S \mathrm{CHL}$

O $10 \mathrm{MG} / \mathrm{M3}$

1

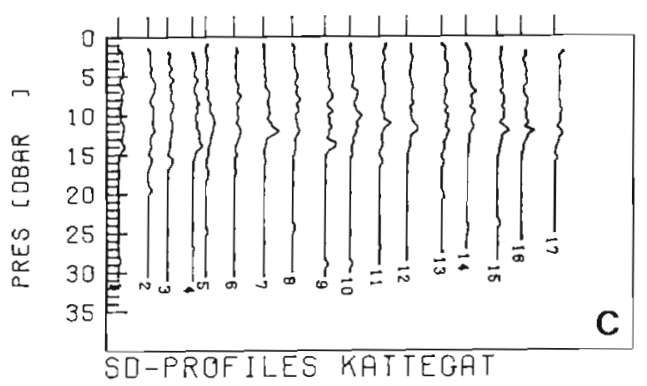

CHL

$-5 \quad M G / M 3$

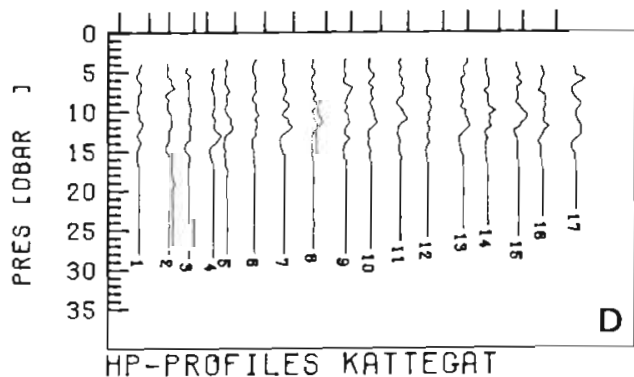

Fig. 12. Chlorophyll distribution during the $16 \mathrm{~h}$ survey in the Kattegat. (A) Original profiles, $\Delta p=0.1$ dbar; (B) mean hourly profiles, $\Delta p=0.5$ dbar; (C) standard deviation profiles, $\Delta p=0.5$ dbar; (D) vertical fine structure (high pass of $B$ ) 

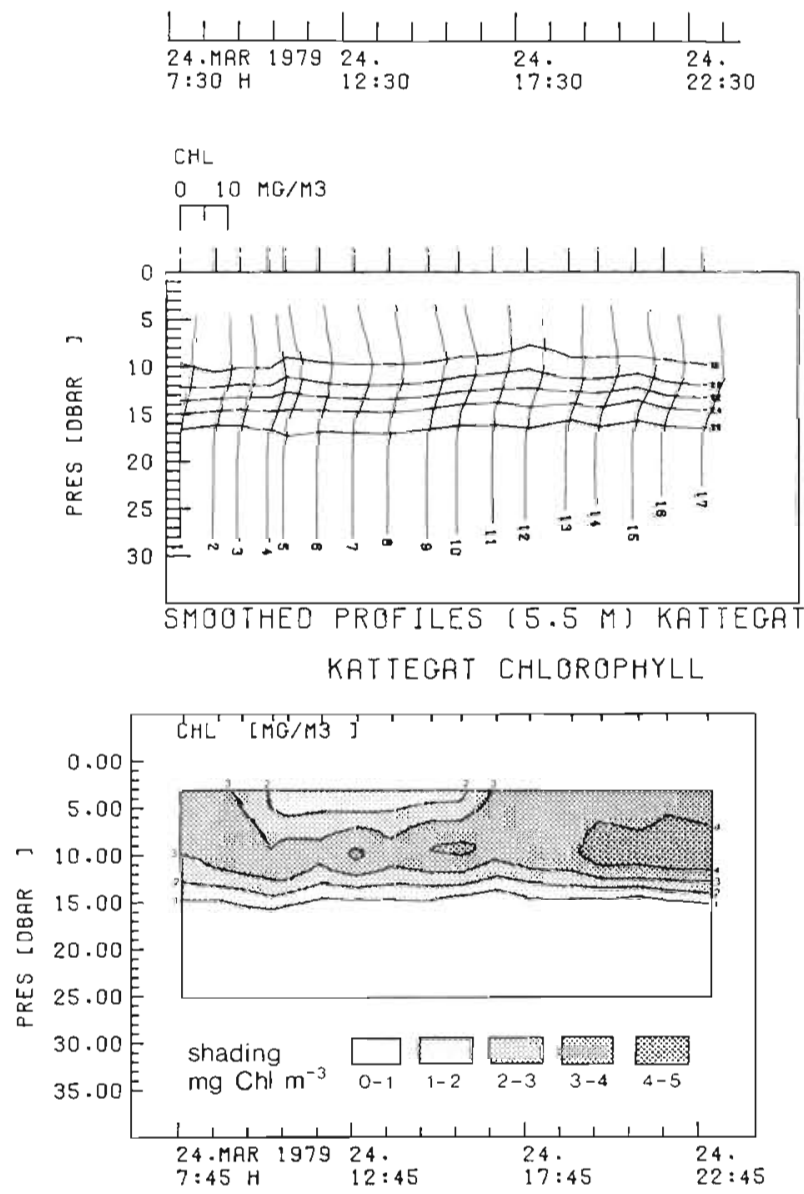

Fig. 13. Chlorophyll layers and vertical variability of $\sigma_{t^{-}}$ isolines during Kattegat drift station

a density axis would have been appropriate only for an isolated study of the pycnocline because of the weak density gradients in the top and bottom layers. We therefore chose to reduce the vertical resolution, but for a high-resolution study a more sophisticated technique should be used. Maximal amplitudes (Table 3) were considerably higher within hourly mean profiles than within burst profiles, because the depth position of the pycnocline changed during the survey (bottom topography, current speed, etc.).

\section{Mesoscale chlorophyll patchiness}

The grand mean profiles (cf. Fig. 10) of temperature, salinity, and chlorophyll give an impression of the mesoscale vertical patchiness and hydrography, after

\footnotetext{
- Some irregularities in nutrient profiles result from the scatter of samples taken successively at about the same depths. They reflect horizontal variability rather than vertical structure
}

Table 3. Mean depth position, variability and maximal amplitude $(\mathrm{m})$ of $\mathrm{o}_{\mathrm{t}}$-isolines during Kattegat drift station

\begin{tabular}{|ccccc|}
\hline$\sigma_{\mathrm{\imath}}$ & $\begin{array}{c}\text { Within burst } \\
\text { No. 7 } \\
\text { (Fig. 11: } \\
\text { prof. 28-32) }\end{array}$ & $\begin{array}{c}\text { Max. } \\
\text { ampl. }\end{array}$ & $\begin{array}{c}\text { Within hourly } \\
\text { mean } \\
\text { (Fig. 13A: } \\
\text { prof. 1-17) }\end{array}$ & $\begin{array}{c}\text { Max. } \\
\text { ampl. }\end{array}$ \\
\hline & $11.0 \pm 0.5$ & 1.0 & $9.1 \pm 0.7$ & 2.8 \\
18 & $12.0 \pm 0.2$ & 0.6 & $11.2 \pm 0.6$ & 2.0 \\
20 & $12.5 \pm 0.2$ & 0.6 & $12.7 \pm 0.5$ & 2.1 \\
24 & $14.5 \pm 0.2$ & 0.4 & $14.1 \pm 0.4$ & 1.2 \\
26 & $15.6 \pm 0.3$ & 0.7 & $16.1 \pm 0.4$ & 1.4 \\
\hline
\end{tabular}

averaging out all the microscale phenomena presented in the previous section. The corresponding standard deviation profiles provide at least some idea of the degree of mesoscale patchiness, the relative amounts of which in the spatial and temporal regimes cannot be precisely determined.

The inflexion-points of the temperature profiles were used to define water-layer boundaries. Chlorophyll layers are, not so comfortably, defined between local chlorophyll minima. Because of the great variety of distribution patterns of the various phytoplankton species observed (Sperling, 1981), no single chlorophyll peak can be attributed exclusively to a particular dominant species.

The mean profiles of chlorophyll and sigma-t will be presented below together with the nutrient data from water samples (for methods see Astheimer, 1982) ${ }^{\circ}$. An individual interpretation of nutrient profiles does not appear very rewarding because they show no relation to the mean chlorophyll profiles but generally run parallel to the mean density profiles (see esp. $\mathrm{NO}_{3}$ in the Kattegat). Nutrient concentrations commonly increase with depth; only in the Kattegat and Bornholm Basin does the distribution of silicate depart from this rule.

\section{Skagerrak}

Four layers of water can be easily discriminated by the temperature profile (Fig. 14 A). Temperature variability (standard deviation 'STEM', Fig, 14 B) has local maxima in the center of each water mass. Temperature and salinity vary maximally at a depth of $7 \mathrm{~m}$ due (probably) to advection and to vertical motion induced by internal waves.

There are 3 distinct phytoplankton layers expressed by the chlorophyll profile. Layer thickness and maximal chlorophyll concentration both decrease with depth. The upper 2 chlorophyll maxima coincide with the water-layer boundaries. The $1 \%$ light level is at $20 \mathrm{~m}$ depth. 


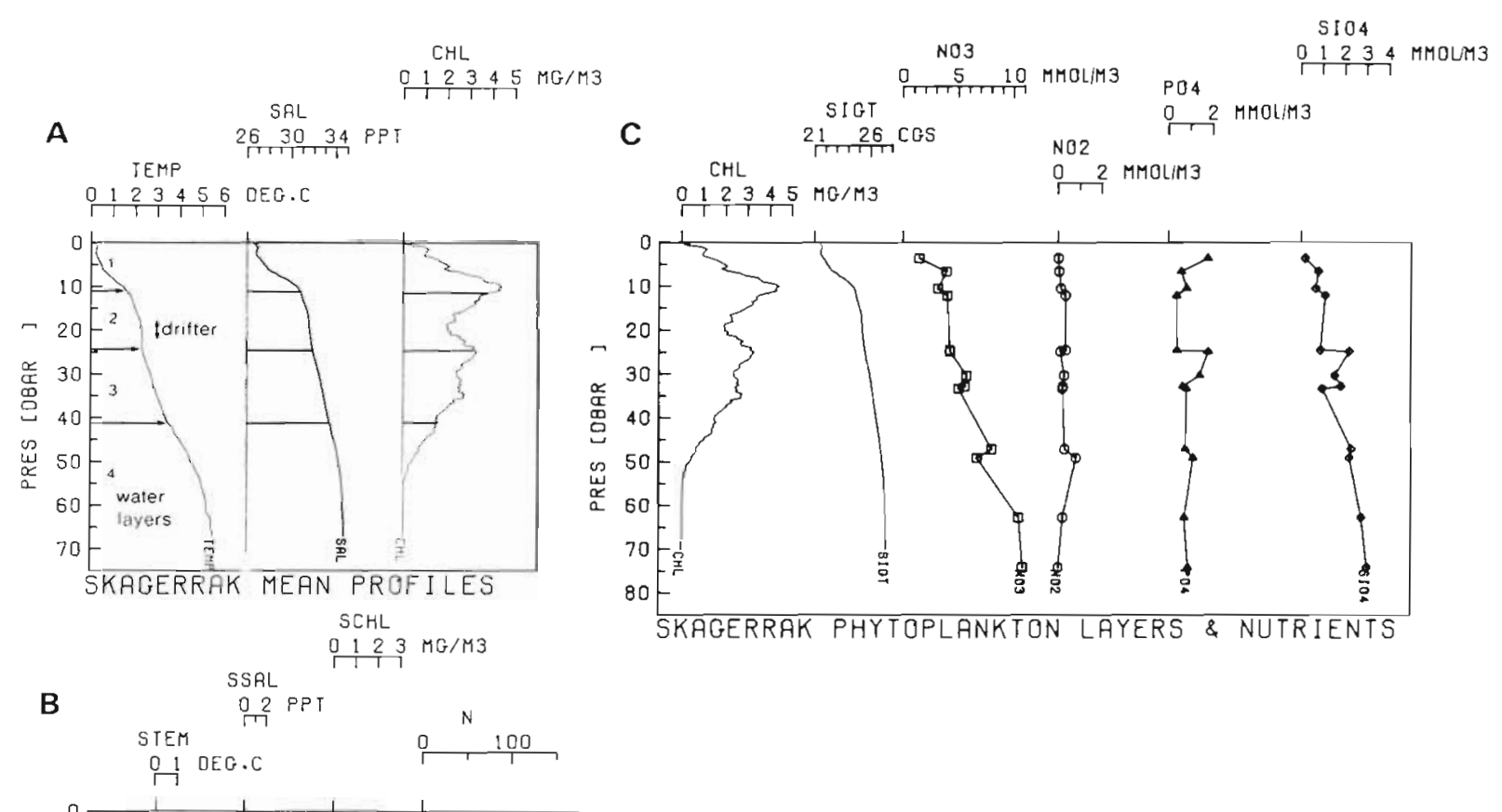

Fig. 14. Skagerrak. (A) mean profiles and water layers; (B) variability (standard deviation of $\mathrm{T}, \mathrm{S}$ and chlorophyll) and number of data points per averaging interval $(\Delta p=$ 0.5 dbar); (C) phytoplankton layers (chlorophyll, density) and nutrients (nitrate, nitrite, phosphate, silicate)

20
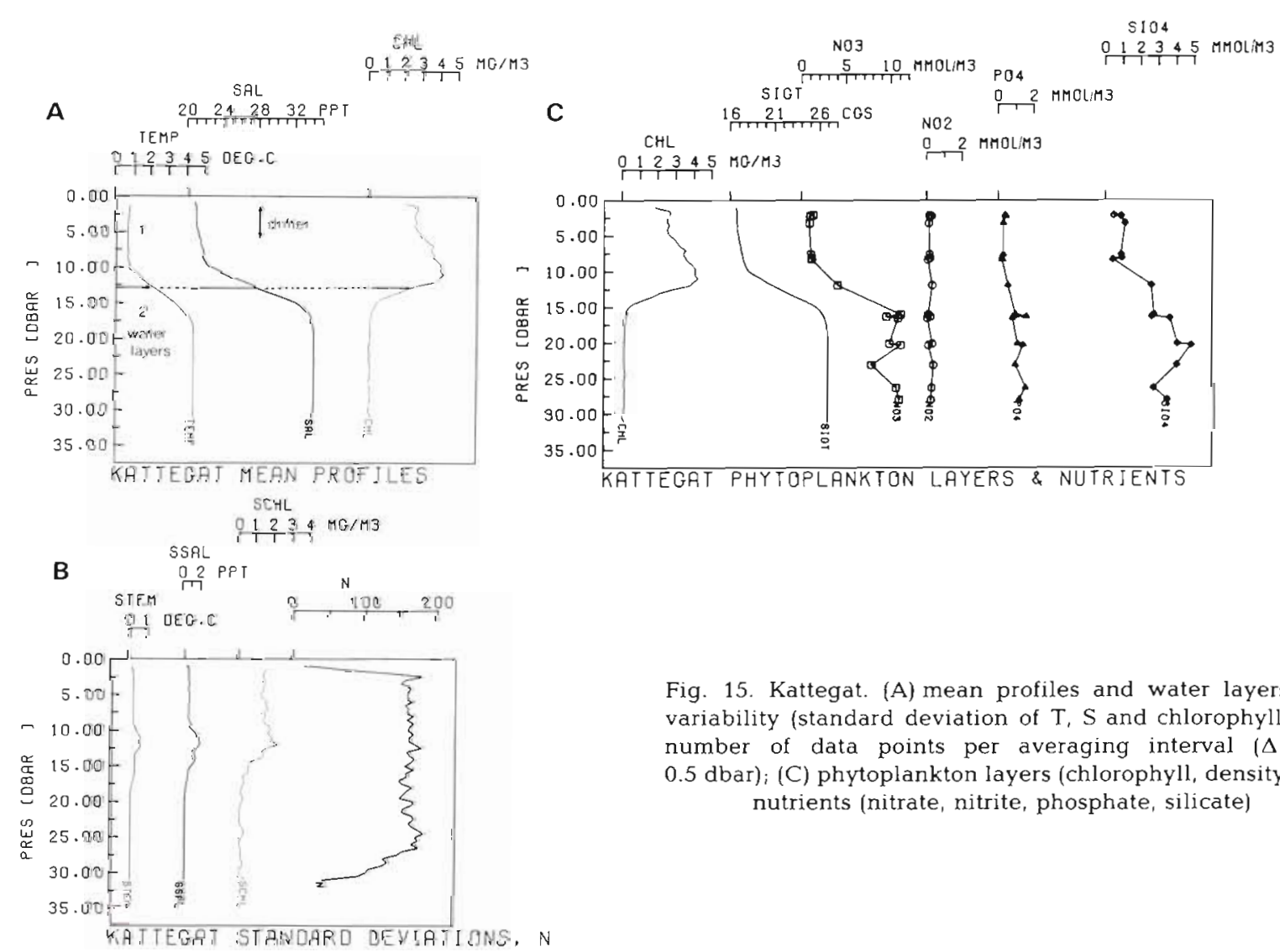

Fig. 15. Kattegat. (A) mean profiles and water layers; (B) variability (standard deviation of $T, S$ and chlorophyll) and number of data points per averaging interval $(\Delta \mathrm{p}=$ $0.5 \mathrm{dbar})_{i}$ (C) phytoplankton layers (chlorophyll, density) and nutrients (nitrate, nitrite, phosphate, silicate) 


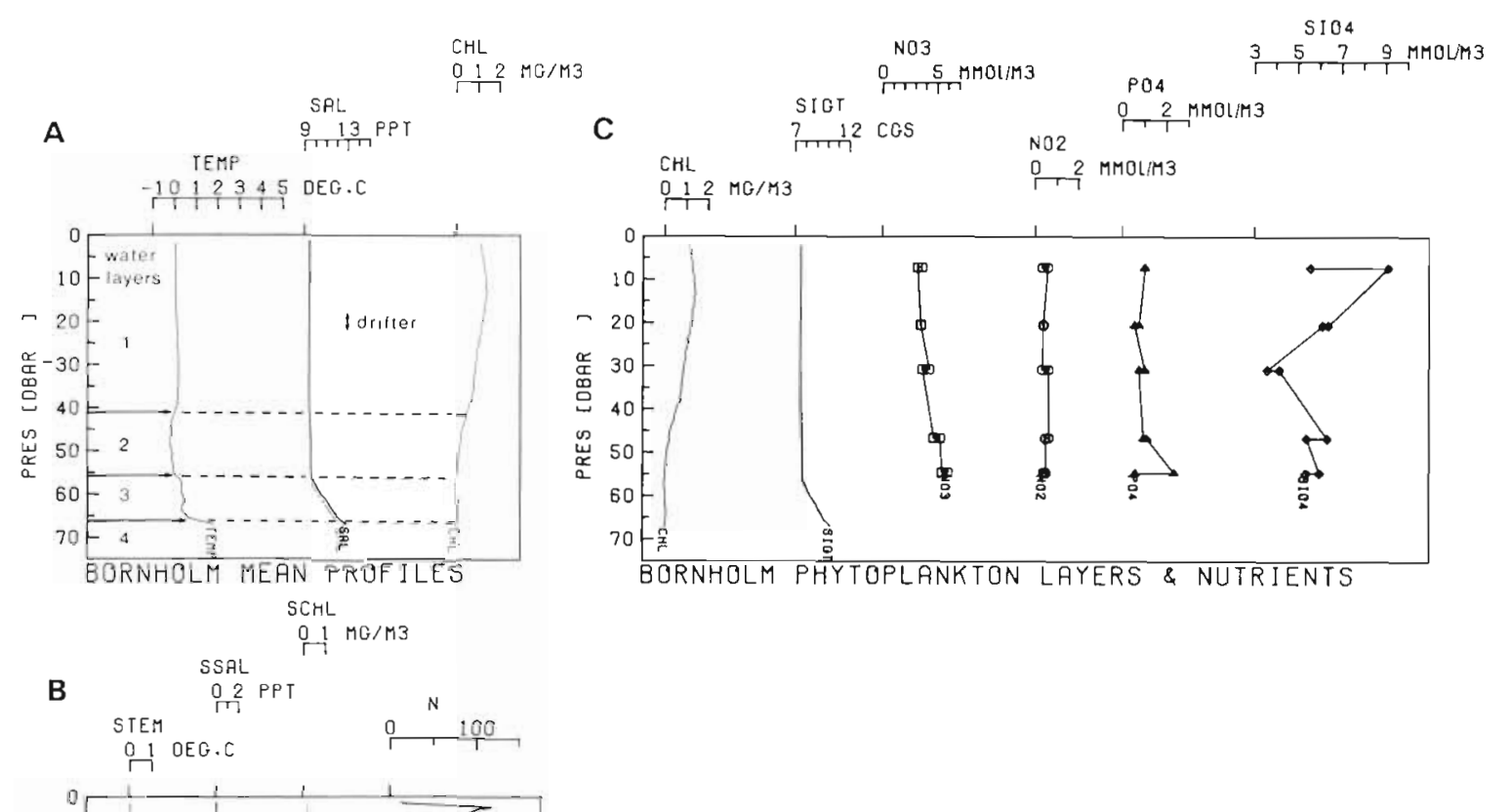

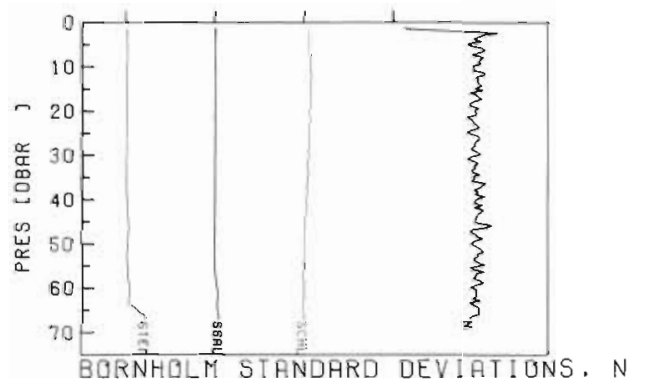

Kattegat

Baltic surface water $\left(\mathrm{T} \approx 0.8{ }^{\circ} \mathrm{C}, \mathrm{S} \approx 21 \%\right.$ ) is separated from North Sea bottom water $\left(\mathrm{T} \approx 4.3{ }^{\circ} \mathrm{C}, \mathrm{S} \approx\right.$ $34 \%$ ) by an extremely strong pycnocline $(\Delta \mathrm{T} / \Delta \mathrm{z} \approx$ $0.47^{\circ} \mathrm{C} \mathrm{m}^{-1}, \Delta \mathrm{S} / \Delta \mathrm{z} \approx 2 \% \mathrm{~m}^{-1}$ ). All variables show maximum variation at $11 \mathrm{~m}$, in the region of the steepest density gradient. The chlorophyll maximum is found there, too, whereas the $1 \%$ light level is encountered at $16 \mathrm{~m}$.

\section{Bornholm}

The water column is invariable with time and homogeneous down to a depth of $40 \mathrm{~m}$. Because the mixed layer depth exceeds the euphotic zone $11 \%$ light level at $20.5 \mathrm{~m}$ ), the chlorophyll concentration is generally fairly small. It reaches its maximum of $1.4 \mathrm{mg} \mathrm{m}^{-3}$ at $13 \mathrm{~m}$. Three more layers of water indicating earlier mixing events can be distinguished below the euphotic zone. They carry almost no chlorophyll but still contain phytoplankton cells (more than $10^{5}$ per litre for the most abundant species).
Fig. 16. Bornholm. (A) mean profiles and water layers; (B) variability (standard deviation of $T, S$ and chlorophyll) and number of data points per averaging interval $(\Delta p=$ $0.5 \mathrm{dbar}$ ); (C) phytoplankton layers (chlorophyll, density) and nutrients (nitrate, nitrite, phosphate, silicate)

\section{DISCUSSION}

\section{Fluorometer}

During laboratory calibration (Fig. 5 B-D), ca. $10^{-9}$ to $5 \cdot 10^{-6} \mathrm{mg}$ chlorophyll were present in the sampling volume of ca. $0.1 \mathrm{ml}$, corresponding to ca. 10 to $3 \cdot 10^{4}$ Dunaliella cells. Mixed populations in the sea may require an additional calibration to remove the effect of variable fluorescence yields, especially under highly variable illumination conditions. Sampling volumes (sonde, water bottles) should be of the same size in order to obtain comparable fluorometric and photometric data.

The small sampling volume of the instrument gives rise to a high level of background noise, the amplitude of which depends directly on the ratio chlorophyll concentration/number of particles. Spikes may originate either from a single big particle ('clump') or from a series of numerous small particles ('micropatch'). In the Kattegat, chlorophyll peaks of an average thickness of $1 \mathrm{~m}$ were composed of about 20 data points and contained up to $8 \mathrm{mg}$ chlorophyll $\mathrm{m}^{-3}$. Based on a typical chlorophyll content of $6.7 \cdot 10^{-10} \mathrm{mg} \mathrm{cell}^{-1}$ (Nusch 
and Palme, 1975), the measuring volume then contained up to $1.2 \cdot 10^{3}$ cells sample $e^{-1}$. We call these peaks 'micropatches' because it is unlikely that they were a result of several successive cell clumps which we never observed under the microscope.

\section{Phytoplankton patchiness}

Singular peaks in original chlorophyll profiles must be considered local phenomena. Variability within burst profiles reflects the degree of horizontal micropatchiness, since sampling was never repeated in exactly the same water column. In case a single fluorescence profile is very noisy, it cannot be considered representative of the general phytoplankton distribution. For conventional mesoscale studies, several consecutive profiles must then be averaged or the sampling volume of the sonde must be enlarged. Except at the Bornholm Station, the highest chlorophyll concentrations are always found in the center of a strong density gradient. Zonation of the water column into several layers apparently favors the formation of plankton patches.

In the Skagerrak we find 4 layers containing ca. $106 \mathrm{mg} \mathrm{Chl} \mathrm{m}{ }^{-2}$. In the Kattegat, chlorophyll totals $37 \mathrm{mg} \mathrm{m}^{-2}$ in 2 layers. There, the pycnocline is so strong that either phytoplankton cannot sink into the lower layer or, if they can, their concentration becomes rapidly diluted in the aphotic zone. Despite the low temperature at the Bornholm Station, the spring bloom had also started there, producing ca. $46 \mathrm{mg} \mathrm{Chl} \mathrm{m}^{-2}$ by the end of March 1979. Chlorophyll concentrations and cell counts are low only because of the absence of an effective stratification within the euphotic zone.

Formation and dispersion of chlorophyll patches in the vicinity of fronts or pycnoclines (Hobson and Lorenzen, 1972; Pingree et al., 1975; Savidge, 1976; Wroblewski, 1976; Herman and Denman, 1979; Astheimer, 1983) is difficult to observe in the presence of advection, vertical density oscillations, and a great variety of patch sizes - even if biological processes like reproduction, destruction and grazing are negligible during a short-term survey. Simultaneous measurement of dispersion of an artificial dye and of chlorophyll appears to be a promising strategy for future work.

Acknowledgements. H. Baumann, H. Heckt, H. Pischke, Drs. P. Diehl and L. Ginskey assisted in operating the Multisonde. P. Fritsche, B. Gotze and M. Sepulveda-Garcia did most of the planktological sampling. Professor B. Zeitzschel, Institut für Meereskunde, Kiel, supported this survey. Drs. J. Rathlev, J. Kielmann and $W$. Zenk provided valuable advice in data processing and interpretation.

\section{LITERATURE CITED}

Aiken, J. (1981). A chlorophyll sensor for automatic, remote, operation in the marine environment. Mar. Ecol. Prog. Ser 4: 235-239

Astheimer, H. (1982). Die Variabilität der Phytoplanktonschichtung in driftenden Wasserkörpern. (The variability of phytoplankton layers in drifting bodies of water.) Ber. Inst. Meeresk. Kiel 98: 1-132

Astheimer, H. (1983). Phytoplankton patches in the Skagerrak, Kattegat, and Bornholm Basin. In: Sündermann, J. Lenz, W. (ed.) North Sea dynamics. Springer Verlag, Berlin, p. 611-631

Denman, K. L. (1977). Short term variability in vertical chlorophyll structure. Limnol. Oceanogr. 22(3): 434-441

Derenbach, J. B., Astheimer, H., Hansen, H. P., Leach, H. (1979). Vertical microscale distribution of phytoplankton in relation to the thermocline. Mar Ecol. Prog. Ser 1: $187-193$

Fasham, M. J. R., Pugh, P. R., Griffiths, D., Wheaton, J. E. G. (1981). Subaquatracka: a submersible fluorometer for the detection of chlorophyll. Conference on Electronics for Ocean Technology, Birmingham, p. 49-58

Früngel, F., Knutel, W., Suarez, J. F. (1971). Pulse light fluorimeter in oceanological measuring techniques. Meerestechnik 6: 241

Früngel, F., Koch, C. (1976). Practical experience with the Variosens equipment in measuring chlorophyll concentrations and fluorescent tracer substances, like Rhodamine, Fluorescein, and some new substances. IEEE J. Ocean. Engn 1: 21-32

Früngel, F., Koch, C. (1980). A new in situ fluorometer for the measurement of fluorescent tracer substances with an exact logarithmic response over four decades. Meerestechnik 11 (3): 107-112

Gessner, F. (1948). The vertical distribution of the phytoplankton and the thermocline. Ecology 29: 386-389

Herman, A. W. (1975). Chlorophyll and dye detection with the Variosens fluorometer. Bedford Inst. Oceanogr. Rep. Ser. BI-R-75-2: 1-37

Herman, A. W., Denman, K. L. (1977). Rapid underway profiling of chlorophyll with an in situ fluorometer mounted on a Batfish vehicle. Deep Sea Res. 24: 385-397

Herman, A. W., Denman, K. L. (1979). Intrusions and vertical mixing at the shelf/slope water front south of Nova Scotia. J. Fish. Res. Bd Can. 36 (12): 1445-1453

Hobson, L. A., Lorenzen, C. J. (1972). Relationship of chlorophyll maxima to density structure in the Atlantic Ocean and Gulf of Mexico. Deep Sea Res. 19: 297-306

Horwood, J. W. (1976). A critical investigation of small scale variability in phytoplankton. Coun. Meet. int. Coun. Explor Sea C.M.-IC.ES/L. 7: 1-6

Horwood, J. W. (1978). Observations on spatial heterogeneity of surface chlorophyll in one and two dimensions. J. mar. biol. Ass. U. K. $58(2)$ : 487-502

Hundahl, H., Holck, J. (1980). A new in situ fluorometer for detection of Rhodamine $B$ and chlorophyll. Institute of Physical Oceanography, Copenhagen, Report 42

Jeffrey, S. W., Humphrey, G. F. (1975). New spectrophotometric equations for determining chlorophylls $a, b, c_{1}$ and $c_{2}$ in higher plants, algae and natural phytoplankton. Biochem. Physiol. Pflanzen 167: 191-194

Kahru, M. Aitsam, A., Elken, J. (1981). Coarse-scale spatial structure of phytoplankton standing crop in relation to hydrography in the open Baltic Sea. Mar. Ecol. Prog. Ser. 5(3): $311-318$ 
Kiefer, D. A. (1973). Fluorescence properties of natural phytoplankton populations. Mar. Biol. 22: 263-269

Kierstead, H., Slobodkin, L. B. (1953). The size of water masses containing plankton blooms. J. mar. Res. 12: 141-147

Kreps, E., Verbinskaya, N. (1930). Seasonal changes in the Barents Sea. J. Cons perm. int. Explor. Mer 5: 329-346

Kroebel, W., Diehl, P., Ginzkey, L., Mahrt, K.-H., Rathlev, J., Siara, R., Schulz, Th. (1976). Die Kieler Multisonde der Jahre 1975/76, ihre Sensoren, Parameter mit Ergebnissen von Datenaufnahmen und Perspektiven für ihre Auswertungen. Inter-Ocean 76 Kongress-Berichtswerk (2): 1034-1046

Loftus, M. E., Seliger, H. H. (1975). Some limitations of the in vivo fluorescence technique. Chesapeake Sci. 16(2): 79-92

Nie, N. H., Hull, C. H., Jenkins, J. G., Steinbrenner, K., Bent, D. H. (1975). SPSS statistical package for the social sciences. McGraw-Hill, New York

Nusch, E. A., Palme, G. (1975). Biologische Methoden für die Praxis der Gewässeruntersuchung: Bestimmung des Chlorophyll-â- und Phaeopigmentgehaltes in Oberflächenwasser. Gas- u. WassFach (Wasser/Abwasser) $116(2): 562-565$

Okubo, A. (1980). Diffusion and ecological problems: mathematical models. Springer Verlag, Berlin

Pingree, R. D., Pugh, P. R., Holligan, P. M., Forster, G. R. (1975). Summer phytoplankton blooms and red tides along tidal fronts in the approaches to the English Channel. Nature, Lond. 258: 672-677

Platt, T., Denman, K. L., Jassby, A. D. (1977). Modeling the productivity of phytoplankton. In: Goldberg, E. D. (ed.)
The sea, Vol. VI, Marine modelling. John Wiley \& Sons, New York, p. 807-856

Rai, H., Marker, A. F. H. (ed.) (1982). Proceedings of the $2^{\text {nd }}$ workshop on the measurement of photosynthetic pigments in freshwaters and standardization of methods. Arch. Hydrobiol., Sonderheft 16

Samuelsson, G., Oquist, G. (1977). A method for studying photosynthetic capacities of unicellular algae based on in vivo chlorophyll fluorescence. Physiol. Plant. 40: 315-319

Savidge, G. (1976). A preliminary study of the distribution of chlorophyll-a in the vicinity of fronts in the Celtic and Western Irish Seas. Estuar. coast. mar. Sci. 4: 617-625

Siedler, G., Hatje, G. (1974). Temperatur, Salzgehalt und Dichte. In: Magaard, L., Rheinheimer, G. (ed.) Meereskunde der Ostsee. Springer Verlag, Berlin, p. 43-60

Slovacek, R. E., Hannan, P. J. (1977). In vivo fluorescence determinations of phytoplankton chlorophyll-a. Limnol. Oceanogr. 22(5): 919-925

Sperling, C. (1981). Zum Zusammenhang zwischen Artenzusammensetzung und summarischen Meßverfahren für die Erfassung des Phytoplanktonbestandes. Diplomarbeit Universität Kiel

Steele, J. H. (1974). Spatial heterogeneity and population stability. Nature, Lond. 248: 83

Stienen, C. (1981). Die Anwendung von optischen in-situMeßmethoden für produktionsbiologische Fragestellungen. Diplomarbeit Universität Kiel

Wroblewski, J. S. (1976). A model of the spatial structure and productivity of phytoplankton populations during variable upwelling off the coast of Oregon. Technical Report, Mesoscale Air-Sea Interaction Group 